\title{
Study on the Effect of Different Pre-Sowing Seed Treatment on Seed Quality of Mustard (Brassica junecea L.)
}

\author{
Y. Rahul Reddy*, Prashant Kumar Rai, A.K. Rai and Bineeta M. Bara
}

Department of Genetics and Plant Breeding, Naini Agricultural Institute, Sam Higginbottom University of Agriculture, Technology and Sciences, Pryagraj, 211007 U. P., India

*Corresponding author

\section{A B S T R A C T}

\begin{tabular}{|l|}
\hline Key w o r d s \\
Mustard, Priming \\
methods, \\
Characters, Gauss, \\
Treatments \\
\hline Article Info \\
\hline $\begin{array}{l}\text { Accepted: } \\
\text { 04 August } 2019 \\
\text { Available Online: } \\
\text { 10 September } 2019\end{array}$ \\
\hline
\end{tabular}

The experiment was conducted in Post Graduate Laboratory, Department of Genetics and Plant Breeding, Sam Higginbottom University of Agriculture, Technology and Sciences, Prayagraj (U.P.) during Rabi season 2018, in order to find out the suitable priming method for Mustard, for different organic and inorganic viz., $\mathrm{T}_{0}$-Untreated (control), $\mathrm{T}_{1}-\mathrm{DH}_{2} \mathrm{O}-(12 \mathrm{hrs}), \mathrm{T}_{2}-\mathrm{KNO}_{3}-1 \%$ (12hrs), $\mathrm{T}_{3}$ $\mathrm{KNO}_{3}-1 \%$ (24hrs), $\mathrm{T}_{4}-\mathrm{NaCl}-1 \%$ (12hrs), $\mathrm{T}_{5}-\mathrm{NaCl}-1 \%$ (24hrs), $\mathrm{T}_{6}-200$ gauss (30min), $\mathrm{T}_{7}-400$ gauss (30min), $\mathrm{T}_{8}-100 \mathrm{~mA}(30 \mathrm{~min}), \mathrm{T}_{9}$-200guass (30min), $\mathrm{T}_{10}$-neem leaf extract@5\%-12hrs and $\mathrm{T}_{11}$-tulsi leaf extract @5\%-12hrs. The seeds were taken and hydrated in their solution for their respective time duration and then dried for $12 \mathrm{hrs}$ under shade. It was found that all the priming treatments showed significance difference with the control while highest germination percentage, Field emergence, Days to $50 \%$ flowering, Number of siliqua per plant, Number of seeds per siliqua, test weight (gm), Seed yield per plant (gm), and seedling character parameters viz.., Germination percentage (\%), Root length $(\mathrm{cm})$, Shoot length $(\mathrm{cm})$, Seedling length $(\mathrm{cm})$, Seedling fresh weight $(\mathrm{gm})$, Seedling dry weight (gm), Vigour index-I, Vigour index -II, Speed of germination were observed for seeds treated with 200 gauss(30min) and plant height, number of primary branches per plant showed nonsignificant difference with control. The study helps to improve the seedling character, growth and nodulation and seed yield with the help of seed priming treatments which are effective, economic, non-toxic and eco-friendly sources.

\section{Introduction}

Mustard is a member of the cruciferace family, which includes broccoli, cabbage, Brussels sprouts, rapeseeds, field rape, canola, Ethiopian mustard and black mustard. Indian mustard (Brassica juncea) is a close relative to canola (B. napus) and Ethiopian mustard (B. campestrus). Edible oilseeds are playing an important role in daily food basket of human being. Mustard (Brassica juncea L.) is one of the first domesticated crops in rabi season. It is widely cultivated in tropical and sub- tropical areas of the world. Globally, it is mainly cultivated in India, Canada, China, Pakistan, Poland, Bangladesh, Sweden and France. About 35\% area of the total cultivated area of world is in India with $16 \%$ of shares in production. Brassica juncea belongs to family brassicaceae and is a very important oil crop. Mustard oil is one of the major edible oils in India. Mustard oil has also got medicinal importance. Residual part of seeds is used as cattle feed and in fertilizer. Indian mustard (Brassica juncea L.) is a fast growing plant which produces a high biomass even in heavy 
metal polluted soils. Brassica oilseed crops, Brassica juncea, B. napus and B. rapa, cover more than 11 million hectares of the world's 6 agricultural land and provide over $8 \%$ of the major oil when grown under a variety of climatic conditions (Downey, 1990). The annual production of Brassica juncea in India reaches alone -ve million tons (FAO, 2003). Mustard seed oil content varies from $35 \%$ to $46 \%$.Mustard seed is the third leading source of vegetable oil in the world after Soya bean oil and palm oil. Mustard seed containing about $40-50 \%$ protein. It is world's second leading sources of protein meal after soybean meal.

India is the fifth major mustard producing country and fourth major mustard consuming country in the world. The major mustard growing states in India are Rajasthan, Uttar Pradesh, Haryana, Madhya Pradesh, Gujarat and West Bengal.

Rajasthan contributes about $49 \%$ to the county's total mustard production, followed by Uttar Pradesh (11\%), Haryana (11\%), Madhya Pradesh (11\%), Gujarat (6\%), West Bengal (5\%) and other districts (7\%). Mustard is grown for its oil rich seeds. Apart from extracting oil, seeds are also used directly in the preparation of almost all Indian curries particularly in a process called "tadka". India occupies the first position both in area and production of mustard.

Seed priming is a technique to reduce emergence time, accomplish uniform emergence time, better algometric (changes in growth of plant parts over time) attributes and provide requisite stand in many horticultural and field crops. Various pre-hydration or priming treatments have been employed to increase the speed and synchrony of seed germination (Bradford, 1986). Common priming techniques include hydropriming, halopriming osmopriming. Hydropriming contributes to significant improvement in seed germination and seedling growth in different plant species. Similar to other priming techniques, hydropriming generally enhances seed germination and seedling emergence, although there are exceptions. During priming, seeds are partially hydrated so that pregerminative metabolic activities proceed, while radical protrusion is prevented, and then are dried back to the original moisture level. Hence, present studies were undertaken to assess the effect of different pre-sowing seed treatments on germination and seedling vigour of Mustard (Brassica juncea L.)

\section{Materials and Methods}

The experiment was conducted in post graduate Seed Testing Laboratory, Department of Genetics and Plant Breeding, Sam Higginbottom University of Agriculture, Technology and Sciences, Pryagraj (U.P.), in order to find out the best priming method for Mustard. 1control and 10 treatments, viz.., $\mathrm{DH}_{2} \mathrm{O}$ (12hrs), $\mathrm{KNO}_{3} @ 1 \%(12 \mathrm{hrs}), \mathrm{KNO}_{3} 1 \%$ (24hrs), NaCl@1\%(12hrs), NaCl@1\%(24hrs), 200guass (30min), 400guass(30min), 100mA (30min), 200mA(30min), Neemleafextract-5\% (12hrs), Tulasi leaf extract-5\%(12hrs) are used to find best priming technique for mustard, seeds were placed on petri plates (Top of the paper method) for germination percentage and speed of germination.

\section{Preparation of chemical solution}

Chemical solutions, $\mathrm{NaCl}, \mathrm{KNO}_{3} 10$ grams of chemical were added with $1000 \mathrm{ml}$ of water.

\section{Preparation of germination media}

Wet tissues were used as germination media and Petridis was used as container. The moisture content of the media was maintained at $80 \%$ of field capacity. 


\section{Yield and yield attributing characters}

Plant height $(\mathrm{cm})$, number of siliqua of ten randomly selected plants, number of seeds of 10 randomly selected siliqua 10 each treatment and replication were recorded at maturity. Weight of total quantity of harvested seeds per plot foe each treatment and replication was recorded and the yield per hectare was calculated and expressed in $\mathrm{q} / \mathrm{ha}-$ 1.

\section{Seed quality parameters}

For seed quality assessment germination test was conducted using the top paper method as prescribed in ISTA rules (1996), by providing the optimum conditions. The germination count was made on normal seedlings and expressed in per cent. Vigour indices were computed by adopting the following formula as suggested by Abdul Baki and Anderson (1973) and expressed in number. Vigour Index $\mathrm{I}=$ Germination $(\%) \mathrm{X}$ Seedling length $(\mathrm{cm})$ Vigour Index II = Germination (\%) $\mathrm{X}$ Seedling dry weight $(\mathrm{g})$.

\section{Data analysis}

The data obtained from different yield and seed quality components were statistically analyzed to find out the significance of the difference among the treatments. The analysis of variance (ANOVA) was performed RBD and CRD.

\section{Results and Discussion}

It is evident from the present investigation that different types of priming methods viz., $\mathrm{DH}_{2} \mathrm{O}$ (12hrs), $\mathrm{KNO}_{3} @ 1 \% 12 \mathrm{hrs}, \mathrm{KNO}_{3} @ 1 \% 24 \mathrm{hrs}$, $\mathrm{NaCl} @ 1 \% 12 \mathrm{hrs}, \mathrm{NaCl} @ 1 \% 24 \mathrm{hrs}, 200$ guass (30min), 400guass (30min), 100mA (30min), 200mA (30min), neemleafextract@5\%12hrs, tulsi leaf extract@5\%-12hrs have positive effect on the growth, yield, yield attributes and seed quality parameters. In general, most of the treatment was found effective in increasing the yield attributes at all stages significantly as compared to control. In the growth, yield attributing parameters such as field emergence, the maximum was recorded in $\mathrm{T}_{6^{-}}$ 98.66 followed by $\mathrm{T}_{7-} 96.33$ and $\mathrm{T}_{11}-94.00$ and the lowest was observed in $\mathrm{T}_{0-85.00}$ field emergence was increased by $13 \%$ compared to control. Days to $50 \%$ flowering, the maximum was recorded in $\mathrm{T}_{6}-39.33$ followed by $\mathrm{T}_{11 \text { - }}$ 39.00 and $\mathrm{T}_{4}-39.00$ and the lowest was observed in $\mathrm{T}_{0}-36.00$ days to $50 \%$ flowering was increased by $4.33 \%$ compared to control. plant height shows non-significant difference compared to control, number of branches, the maximum was recorded in $\mathrm{T}_{6}-7.26$ followed by $T_{11-} 4.73$ and $T_{7}-4.66$ and the lowest was observed in $\mathrm{T}_{0-3} 3.6$ number of branches was increased by $4.20 \%$ compared to control, siliqua per plant, the maximum was recorded in $\mathrm{T}_{6}-90.53$ followed by $\mathrm{T}_{11-} 65.6$ and $\mathrm{T}_{7}-64.33$ and the lowest was observed in $\mathrm{T}_{0-48.06}$ number of siliqua per plant increased by $42 \%$ compared to control, seeds per siliqua the maximum was recorded in $\mathrm{T}_{6}-8.82$ followed by $\mathrm{T}_{7} .8 .78$ and $\mathrm{T}_{3}-8.78$ and the lowest was observed in $\mathrm{T}_{0}-6.96$ seeds per siliqua was increased by $2 \%$ compared to control, test weight, the maximum was recorded in $\mathrm{T}_{6}-0.54$ followed by $\mathrm{T}_{7}-0.52$ and $\mathrm{T}_{11}-0.48$ and the lowest was observed in $\mathrm{T}_{0}-0.39$ test weight was increased by $0.15 \%$ compared to control. seed yield, the maximum was recorded in $\mathrm{T}_{6}$ 4.04 followed by $\mathrm{T}_{1-} 2.65$ and $\mathrm{T}_{7}-2.63$ and the lowest was observed in $\mathrm{T}_{0} 1.79$ seed yield was increased by $2.75 \%$ compared to control as shown in the Table 1.

In seed quality parameters germination percentage, the maximum was recorded in $\mathrm{T}_{6^{-}}$ 98.50 followed by $\mathrm{T}_{7-} 97.50$ and $\mathrm{T}_{11}-97.00$ and the lowest was observed in $\mathrm{T}_{0-85} 8500$ germination percentage was increased by $23.50 \%$ compared to control, root length, the maximum was recorded in $\mathrm{T}_{6}-11.78$ followed 
by $\mathrm{T}_{7-} 11.53$ and $\mathrm{T}_{1}-11.27$ and the lowest was observed in $\mathrm{T}_{0-8} 8.61$ root length was increased by $2.17 \%$ compared to control, shoot length, the maximum was recorded in $\mathrm{T}_{6}-8.54$ followed by $\mathrm{T}_{7}-8.03$ and $\mathrm{T}_{9}-7.77$ and the lowest was observed in $\mathrm{T}_{0} 6.53$ shoot length was increased by $1.50 \%$ compared to control, seedling length, the maximum was recorded in $\mathrm{T}_{6}-19.49$ followed by $\mathrm{T}_{7-} 19.28$ and $\mathrm{T}_{10}-18.25$ and the lowest was observed in $\mathrm{T}_{0}-15.34$ seedling length was increased by $3.15 \%$ compared to control, fresh weight, the maximum was recorded in $\mathrm{T}_{6}-0.7$ followed by $\mathrm{T}_{7 .} 0.53$ and $\mathrm{T}_{3}-0.53$ and the lowest was observed in $\mathrm{T}_{0}-0.38$ fresh weight was increased by $23.50 \%$ compared to control, dry weight of seedlings, the maximum was recorded in $\mathrm{T}_{6-}-0.13$ followed by $\mathrm{T}_{7-} 0.12$ and
$\mathrm{T}_{5}-0.11$ and the lowest was observed in $\mathrm{T}_{0}$ 0.07 dry weight of seedlings was increased by $6 \%$ compared to control, vigour index-1, the maximum was recorded in $\mathrm{T}_{6}-7679.06$ followed by $\mathrm{T}_{7-} 7083.91$ and $\mathrm{T}_{11}-6943.5$ and the lowest was observed in $\mathrm{T}_{0} 5931.3$ vigour index-1, was increased by $21 \%$ compared to control, vigour index-2, the maximum was recorded in $\mathrm{T}_{6}-55.72$ followed by $\mathrm{T}_{7-} 45.08$ and $\mathrm{T}_{5}-39.95$ and the lowest was observed in $\mathrm{T}_{0}-29.25$ vigour index -2 was increased by $16 \%$ compared to control, speed of germination the maximum was recorded in $\mathrm{T}_{6}-97.75$ followed by $T_{7-} 97.25$ and $T_{11}-97.25$ and the lowest was observed in $\mathrm{T}_{0} 85.25$ speed of germination was increased by $8 \%$ compared to control, shown in Table 2.

Table.1 Mean performance of mustard for growth, yield and yield attributes

\begin{tabular}{|l|l|l|c|c|c|c|c|c|c|}
\hline $\begin{array}{l}\text { SI. } \\
\text { NO }\end{array}$ & $\begin{array}{l}\text { Treat } \\
\text { ments }\end{array}$ & $\begin{array}{c}\text { Field } \\
\text { Emergence }\end{array}$ & $\begin{array}{c}\text { Days to } \\
\mathbf{5 0 \%} \\
\text { Flowering }\end{array}$ & $\begin{array}{c}\text { Plant } \\
\text { height }\end{array}$ & $\begin{array}{c}\text { No. of } \\
\text { Branches } \\
\text { per plant }\end{array}$ & $\begin{array}{c}\text { No. of } \\
\text { siliqua } \\
\text { per plant }\end{array}$ & $\begin{array}{c}\text { No. of } \\
\text { seeds per } \\
\text { siliqua }\end{array}$ & $\begin{array}{c}\text { Test } \\
\text { weight }\end{array}$ & $\begin{array}{c}\text { Seed yield } \\
\text { per plant } \\
\text { (gm) }\end{array}$ \\
\hline $\mathbf{1}$ & $\mathbf{T}_{\mathbf{0}}$ & 85.00 & 36.00 & 85.2 & 3.6 & 48.06 & 6.96 & 0.39 & $\mathbf{1 . 7 9}$ \\
\hline $\mathbf{2}$ & $\mathbf{T}_{\mathbf{1}}$ & 93.00 & 37.66 & 96.73 & 4.06 & 59.26 & 8.72 & 0.47 & $\mathbf{2 . 6 5}$ \\
\hline $\mathbf{3}$ & $\mathbf{T}_{\mathbf{2}}$ & 90.66 & 37.33 & 89.66 & 4.00 & 60.33 & 8.52 & 0.42 & $\mathbf{2 . 4 0}$ \\
\hline $\mathbf{4}$ & $\mathbf{T}_{\mathbf{3}}$ & 82.00 & 36.33 & 91.93 & 3.86 & 64.4 & 8.78 & 0.45 & $\mathbf{2 . 5 6}$ \\
\hline $\mathbf{5}$ & $\mathbf{T}_{\mathbf{4}}$ & 87.66 & 39.00 & 98.4 & 3.73 & 50.66 & 8.71 & 0.45 & $\mathbf{2 . 5 3}$ \\
\hline $\mathbf{6}$ & $\mathbf{T}_{\mathbf{5}}$ & 91.66 & 36.66 & 95.53 & 4.4 & 58.8 & 8.51 & 0.43 & $\mathbf{3 . 2 4}$ \\
\hline $\mathbf{7}$ & $\mathbf{T}_{\mathbf{6}}$ & 98.66 & 40.33 & 98.66 & 7.26 & 90.53 & 8.82 & 0.54 & $\mathbf{4 . 0 4}$ \\
\hline $\mathbf{8}$ & $\mathbf{T}_{\mathbf{7}}$ & 96.33 & 39.33 & 97.46 & 4.66 & 64.33 & 8.78 & 0.52 & $\mathbf{2 . 6 3}$ \\
\hline $\mathbf{9}$ & $\mathbf{T}_{\mathbf{8}}$ & 93.00 & 38.66 & 94.53 & 3.93 & 62.33 & 8.69 & 0.42 & $\mathbf{2 . 4 6}$ \\
\hline $\mathbf{1 0}$ & $\mathbf{T}_{\mathbf{9}}$ & 87.66 & 38.33 & 92.53 & 3.8 & 53.2 & 8.25 & 0.48 & $\mathbf{1 . 8 2}$ \\
\hline $\mathbf{1 1}$ & $\mathbf{T}_{\mathbf{1 0}}$ & 92.00 & 38.00 & 96.66 & 4.66 & 55.26 & 8.49 & 0.46 & $\mathbf{2 . 2 1}$ \\
\hline $\mathbf{1 2}$ & $\mathbf{T}_{\mathbf{1 1}}$ & 94.00 & 39.00 & 98.86 & 4.73 & 65.6 & 8.61 & 0.48 & $\mathbf{2 . 6 3}$ \\
\hline GRAND & $\mathbf{9 0 . 9 7}$ & $\mathbf{3 8 . 0 5}$ & $\mathbf{9 4 . 6 8}$ & $\mathbf{4 . 3 9}$ & $\mathbf{6 1 . 0 6}$ & $\mathbf{8 . 4 9}$ & $\mathbf{0 . 4 5}$ & $\mathbf{2 . 5 5}$ \\
\hline $\mathbf{M E A N}$ & & & & & & & & \\
\hline CD(5\%) & 7.89 & 3.96 & 19.27 & 1.64 & 20.26 & 0.87 & 0.06 & $\mathbf{0 . 9 6}$ \\
\hline SEm \pm & 2.69 & 1.35 & 6.57 & 0.56 & 6.91 & 0.30 & 0.02 & $\mathbf{0 . 3 3}$ \\
\hline CV & & $\mathbf{5 . 1}$ & $\mathbf{6 . 1}$ & $\mathbf{1 2 . 0}$ & $\mathbf{2 2 . 1}$ & $\mathbf{1 9 . 6}$ & $\mathbf{6 . 0}$ & $\mathbf{7 . 8}$ & $\mathbf{2 2 . 2}$ \\
\hline
\end{tabular}


Table.2 Mean performances of mustard for seed quality parameters

\begin{tabular}{|c|c|c|c|c|c|c|c|c|c|c|}
\hline $\begin{array}{l}\text { Sl. } \\
\text { No }\end{array}$ & Treatment & $\begin{array}{l}\text { Germination } \\
\text { percentage }\end{array}$ & $\begin{array}{l}\text { Root } \\
\text { Length } \\
(\mathrm{cm})\end{array}$ & $\begin{array}{l}\text { Shoot } \\
\text { Length } \\
(\mathrm{cm})\end{array}$ & $\begin{array}{l}\text { Seedling } \\
\text { Length } \\
(\mathrm{cm})\end{array}$ & $\begin{array}{l}\text { Fresh Weight } \\
\text { of Seedling (g) }\end{array}$ & $\begin{array}{l}\text { Dry Weight } \\
\text { of } \begin{array}{r}\text { Seedling } \\
\text { (g) }\end{array} \\
\end{array}$ & $\begin{array}{l}\text { Seed } \\
\text { Vigour } \\
\text { Index } 1 \\
\end{array}$ & $\begin{array}{l}\text { Seed } \\
\text { Vigour } \\
\text { Index } 2 \\
\end{array}$ & $\begin{array}{l}\text { Speed of } \\
\text { Germination }\end{array}$ \\
\hline 1 & T0 & 85.00 & 8.61 & 6.53 & 15.34 & 0.38 & 0.07 & 5931.3 & 29.25 & 85.25 \\
\hline 2 & $\mathrm{~T} 1$ & 96.00 & 11.27 & 7.54 & 17.55 & 0.64 & 0.10 & 6740.16 & 33.77 & 95.00 \\
\hline 3 & $\mathrm{~T} 2$ & 87.5 & 8.65 & 6.78 & 15.51 & 0.44 & 0.08 & 5369.87 & 30.62 & 92.75 \\
\hline 4 & T3 & 85.5 & 9.09 & 6.67 & 15.59 & 0.53 & 0.10 & 5334.34 & 35.91 & 76.25 \\
\hline 5 & $\mathrm{~T} 4$ & 89.00 & 11.25 & 7.37 & 18.39 & 0.41 & 0.09 & 6547.73 & 29.71 & 89.5 \\
\hline 6 & T5 & 96.5 & 9.29 & 7.33 & 17.44 & 0.60 & 0.11 & 5989.75 & 39.95 & 89.75 \\
\hline 7 & T6 & 98.50 & 11.78 & 8.54 & 19.49 & 0.7 & 0.13 & 7679.06 & 55.72 & 97.75 \\
\hline 8 & $\mathrm{~T} 7$ & 97.50 & 11.53 & 8.03 & 19.28 & 0.53 & 0.12 & 7083.91 & 45.08 & 97.25 \\
\hline 9 & $\mathrm{~T} 8$ & 88.00 & 10.76 & 7.14 & 17.93 & 0.39 & 0.08 & 6314 & 29.92 & 87 \\
\hline 10 & T9 & 85.00 & 8.86 & 7.77 & 17.73 & 0.47 & 0.10 & 6029.05 & 36.55 & 85.25 \\
\hline 11 & T10 & 90.00 & 10.33 & 7.45 & 18.25 & 0.49 & 0.09 & 6061.57 & 37.83 & 96.25 \\
\hline 12 & T11 & 97.00 & 9.08 & 6.91 & 15.54 & 0.45 & 0.08 & 6943.5 & 37.8 & 97.25 \\
\hline \multicolumn{2}{|c|}{ GRAND MEAN } & 91.29 & 10.04 & 7.34 & 17.34 & 0.50 & 0.10 & 6335.35 & 36.843 & 91.72 \\
\hline \multicolumn{2}{|c|}{$\operatorname{CD}(5 \%)$} & 7.516 & 2.256 & 1.007 & 2.536 & 0.1656 & 0.036 & 235.78 & 3.22 & 9.848 \\
\hline \multicolumn{2}{|c|}{ SEm \pm} & 2.62 & 0.786 & 0.351 & 0.884 & 0.057 & 0.012 & 82.20 & 1.125 & 3.433 \\
\hline
\end{tabular}


The magnetic field mechanisms of action on plants germination and seedling growth is not well known yet, however several theories have been proposed, including biochemical changes or altered enzyme activities. Seed germination stimulation might be attributed to a combined effect of biochemical, physiological, metabolic as well as enhanced enzymatic action.

It is assumed that the magnetic field treatment influences the structure of cell membrane and in this way increase their permeability and ion transport in the ion channels, which as a result affects the metabolic pathways. The enzymes which are necessary for seed germination at particular stages of germination were found higher in magnetically treated seeds during seed germination. The magnetic field affects the biological objects by non-conventional spins, free radicals, liquids crystals or mobile electron charges. Chemically these free radicals are very active species, which take part in fast reactions and cause changes in the biochemical and physiological processes during seed germination and an increase in water uptake rate due to magnetic field treatment was found, which may be responsible for increased pea seed germination as well as seedling growth and at lateral stages of development (Labes, 1993; Podleœny et al., 2004; Wards, 1978).

On the basis of experimental results it may be concluded that better growth and yield was observed in $\mathrm{T}_{6}$ (200guass@30min) and superior than control followed by $\mathrm{T}_{7}$ (400guass@30min) and $\mathrm{T}_{11}$ (tulasi leaf extract (a) 5\% at 12hrs) significantly increased the quality parameters and yield attributes of mustard. From the present investigation i suggest that magneto priming is suitable priming technique for mustard, it is ecofriendly and economic in use. I suggest the on-farm trails to popularize this concept. Onfarm trails means some farmers are selected and armed with knowledge of safe limits for soaking, time of exposure of magnetic and electric fields and evaluate the trails during farm walks and group discussion. On farm seed priming is a key technology low cost with low risk to produce an immediate benefit, unlocking the farming system and giving the farmer reasonable access to further benefits.

\section{References}

Abdul-Baki, A. A. and Anderson, J. D. (1973). Vigour determination in soybean by multiple criteria. Crop Science, 13: 630-633.

Afzal I, Ashraf S, Qasim M, Basra SMA, Shahid M. Does halopriming improve germination and seedling vigour in marigold (Tagetes spp.) Seed Science Technology. 2009; 37: 436-445. 2.

Afzal I, Basra SMA, Ahmad N, Cheema MA, Warraich EA, Khaliq A Effect of priming and growth regulator treatment on emergence and seedling growth of hybrid maize (Zea mays). Int. J. Agric. Biol. 2002; 4: 303- 306. 3.

Amarnath, B. H. Chaurasia A.K, Arvind K. 2013. Effect of priming with botanicals and animal waste on germination and seedling vigour in sorghum (Sorghum bicolor L) seeds Advances in Research, 2015, 6(10):73-77.

Anna, A. 2002. Study of the influence of magnetic field on some biological characteristics of Zea mays. Journal of Central European Agric. 3: 89-94.

Applied Science Deepti, P., Negi, S. 2015. Effect of Seed Priming with Some Plant Leaf Extract on Seedling Growth Characteristics and Root Rot Disease in International Journal of Agriculture System (1JAS) Tomato. 4(1):132-135.

Arif M, Jan MT, Marwat KB, Khan MA. Seed priming improves emergence and yeild of Soybean. Pak. J. Bot, 2007; 
40(3): 1169-1177. 4. The sweet corn seeds harvested at different times. Bragantia. 65(4): 687-692.

Asharf M. and Foolad M.R., (2005) Presowing treatment- a shotgun approach to improve germination growth and crop yield under non-saline condition. Advance Agronomy. 88: 223271.

Basra, S. M. A., Zia, M. N., Mahmood, T., Afzal, I. and Khaliq, A., (2003) Comparison of different invigoration techniques in wheat (Triticum aestivum L.) seeds. Pakistan Journal of Arid Agriculture, 2:11-16.
Bhatnagar, D. and Deb, A.R. 1977. Some aspects of pre-germination exposure of wheat seeds to magnetic fields. Seed germination and early growth. Seed Res. 5: 129-137

Bovy A, de Vos R, Kemper M, et al., Highflavonol tomatoes resulting from the heterologous expression of the maize transcription factor genes $\mathrm{LC}$ and $\mathrm{C} 1$.

Canene-Adams K, Campbell JK, Zaripheh S, Jeffery EH, Erdman Jr JW. The tomato as a functional food. Journal of Nutrition 2005; 135: 1226-1230. 6.

\section{How to cite this article:}

Rahul Reddy, Y., Prashant Kumar Rai, A.K. Rai and Bineeta M. Bara. 2019. Study on the Effect of Different Pre-Sowing Seed Treatment on Seed Quality of Mustard (Brassica junecea L.). Int.J.Curr.Microbiol.App.Sci. 8(09): 26-32. doi: https://doi.org/10.20546/ijcmas.2019.809.004 